\title{
EFEKTIVITAS MODEL PAKEM DALAM MENINGKATKAN KONSENTRASI BELAJAR ANAK USIA DINI
}

\author{
Wahyu Wijayanti \\ Institut Agama Islam Negeri Ponorogo \\ Email: ayukwijayanti20@gmail.com \\ Mukhlison Efendi \\ Institut Agama Islam Negeri Ponorogo \\ E-mail: effendi@iainponorogo.ac.id
}

\begin{abstract}
When learning takes place, the child cannot complete the task given by the teacher, the child cannot pay attention to the teacher when telling stories, the child is still talking to himself, the child likes to run alone which causes a lack of concentration in learning in children. Observing these conditions to increase children's learning concentration requires a method or technique that is considered interesting and fun. One of the efforts to increase children's learning concentration is through a learning model. This study aims to examine the planning, implementation, and evaluation of the PAKEM learning model in increasing the concentration of early childhood learning at Khairiah Jimbe Islamic Kindergarten Jenang Ponorogo. This research uses a qualitative approach with the type of case study research. The data collected is in the form of primary and secondary data derived from observations, interviews, and documentation. The data analysis technique follows the concepts put forward by Miles and Huberman, namely data reduction, data presentation and conclusion drawing. Based on the analysis of this research data, it can be concluded that the PAKEM learning planning is in accordance with Permendikbud Number 146 of 2014 Article 2013, the implementation of the PAKEM learning model in increasing the concentration of early childhood learning is very good, it can be seen from the teachers actively and creatively in teaching and giving assignments and evaluation of learning. In increasing the concentration of early childhood learning, it is adjusted to indicators of developmental achievement and refers to assessment standards.
\end{abstract}

Keywords: Learning Model, Learning Concentration, Early Childhood.

Abstrak: Saat pembelajaran berlangsung, anak belum bisa menyelesaikan tugas yang diberikanoleh guru, Anak belum bisa memperhatikan guru saat bercerita, anak masih berbicara sendiri, Anak senang berlari lari sendiri menyebabkan kurangnya konsentrasi belajar pada anak. Mencermati kondisi tersebut untuk meningkatkan konsentrasi belajar anak memerlukan suatu cara atau teknik yang dianggap menarik dan menyenangkan. Salah satu upaya untuk meningkatkan konsentrasi belajar anak adalah melalui model pembelajaran. Penelitian ini bertujuan untuk mengkaji perencanaan, pelaksanaan, dan evaluasi model pembelajaran PAKEM dalam meningkatkan konsentrasi belajar anak usia dini.di TK Islam Khairiah Jimbe Jenangan Ponorogo. Penelitian ini menggunakan pendekatan kualitatif dengan jenis penelitian studi kasus. Data yang dihimpun berupa data primer dan sekunder yang berasal dari observasi, wawancara, dan dokumentasi. Adapun teknik analisis data mengikuti konsep yang dikemukakan oleh Miles dan Huberman yaitu reduksi data, penyajian data dan penarikan kesimpulan. Berdasarkan analisis data penilitian ini dapat disimpulkan bahwa perencanaan pembelajaran PAKEM sesuai dengan Permendikbud Nomor 146 Tahun 2014 Pasal 2013, Implementasi model pembelajaran 
Wahyu Wijayanti, Mukhlison Efendi, Efektivitas Model Pakem dalam Meningkatkan Konsentrasi Belajar Anak Usia Dini

PAKEM dalam meningkatkan konsentrasi belajar anak usia dini sangat baik, terlihat dari guru secara aktif dan kreatif dalam mengajar dan memberikan tugas dan evaluasi pembelajaran dalam meningkatkan konsentrasi belajar anak usia dini disesuaikan dengan indikator pencapaian perkembangan dan mengacu pada standar penilaian.

Kata kunci: Model Pembelajaran, Konsentrasi Belajar, Anak Usia Dini.

\section{PENDAHULUAN}

Taman kanak-kanak adalah salah satu bentuk satuan pendidikan anak usia dini pada jalur pendidikan formal yang menyelenggarakan program pendidikan bagi anak usia empat tahun sampai enam tahun. tujuannya adalah untuk membantuk anak didik mengembangkan berbagai potensi baik psikis dan fisik yang meliputi moral dan nilai-nilai agama, sosial, emosional, kognitif, bahasa, fisik atau motorik, kemandirian dan seni untuk siap memasuki pendidikan dasar. Oleh karena itu, tujuan TK adalah pembentukan dasar untuk mengembangkan potensi yang dimiliki anak usia dini.

Dalam hal itu keluarga mempunyai peranan penting untuk mewujudkan peletakan dasar dalam rangka memasuki jenjang pendidikan selanjutnya. Program kegiatan TK, didasarkan pada tugas perkembangan anak sesuai dengan tahap perkembangannya. Program kegiatan belajar TK merupakan satu kesatuan program keagamaan sebagai bagian dari aspek kepribadian yang terintegrasi dan pertumbuhan psikis. Pembentukan nilainilai kesopanan atau nilai-nilai yang berkaitan dengan aspek spiritual akan lebih efektif jika seorang berada dalam lingkungan yang menjujung tinggi nilai-nilai tersebut. Jadi, ada hubungan antara lingkungan dan sikap masyarakat lain yang memiliki ikatan longgar terhadap norma-norma keagamaan dibandingkan dengan masyarakat lain yang memiliki ikatan longgar terhadap norma-norma keagamaan. Dengan demikian, fungsi dan peran masyarakat dalam pembentukan jiwa keagamaan akan sangat tergantung dari seberapa jauh masyarakat tersebut menjujung normanorma keagamaan itu sendiri. 
Secara institusional, Pendidikan Anak Usia Dini juga dapat diartikan sebagai salah satu bentuk penyelenggaraan pendidikan yang menitik beratkan pada peletakan dasar kearah pertumbuhan dan perkembangan, baik koordinasi motorik halus dan kasar, kecerdasan emosi, kecerdasan jamak maupun kecerdasan spiritual. Sesuai dengan keunikan dan pertumbuhan anak usia dini, penyelenggaraan pendidikan bagi anak usia dini disesuaikan dengan tahap-tahap perkembangan yang dilalui oleh Anak Usia Dini. 1

Undang-undang tahun 2003 tentang Sistem Pendidikan Nasional pasal 28 telah mengamanatkan dengan tegas perlunya penanganan pendidikan anak usia dini. Di dalam tujuan pendidikan nasional ditekankan adanya stimulasi atau rangsangan bagi perkembangan potensi anak, agar menjadi manusia beriman dan bertakwa kepada Tuhan Yang Maha Esa, berakhlak mulia, sehat, berilmu, cakap, kritis, kreatif, inovatif, mandiri, percaya diri, dan menjadi warga Negara yang demokratis dan bertanggung jawab². Sumber atau penyalurnya yaitu guru pada sasaran atau penerima pesan yakni siswa kanak-kanak yang sedang melakukan pendidikan.

Tujuan pembelajaran adalah untuk mengembangkan seluruh potensi anak agar kelak dapat berfungsi sebagai manusia yang utuh sesuai falsafah suatu bangsa. Atas dasar ini, anak dapat dipandang sebagai individu yang baru mengenal dunia, belum mengetahui tatakrama, sopan santun, aturan, norma, etika, dan berbagai hal tentang kehidupan ini. Karena itu, anak perlu dibimbing agar mampu memahami berbagai hal tentang dunia dan isinya. Adapun komponen model pembelajaran meliputi konsep, tujuan pembelajaran, standar kompetensi dan kompetensi dasar, materi, prosedur, metode, sumber belajar, dan teknik evaluasi. Pembelajaran aktif, kratif, efektif, dan menyenangkan anak usia dini merupakan pembelajaran

${ }^{1}$ Mansur, Pendidikan Anak Usia Dini dalam Islam (Yogyakarta:Pustaka Pelajar, 2005), 127-365.

2 Djamila Lasaiba, Pola Pengembangan Model Pembelajaran Pendidikan Anak Usia Dini di Lingkar Kampus IAIN Ambon, Jurnal Fikratuna, Volume 8 Nomor 2, 2016, h. 84 
yang memungkinkan siswa melakukan kegiatan yang beragam untuk mengembangkan keterampilan, sikap dan pemahaman dengan mengutamakan belajar sambil bekerja, guru mengunakan berbagai sumber belajar dan alat bantu termasuk pemanfaatan lingkungan sebagai sumber belajar agar pembelajaran lebih menarik, menyenangkan, dan efektif.

Guru tidak sekedar menyampaikan materi, akan tetapi secara kontinyu, siswa diajak berpikir secara aktif seperti bertaya, bekerja secara individu maupun kelompok dan berpartisipasi dalam kegiatan pembelajaran sehingga pembelajaran tidak membosankan. ${ }^{3}$ Karena model pembelajaran aktif kreatif efektif dan menyenangkan (PAKEM) merupakan komponen dari proses pendidikan yang harus dikuasai oleh seorang guru dalam proses meningkatkan konsentrasi belajar anak.

Proses pembelajaran pada model pembelajaran aktif kreatif efektif dan menyenangkan (PAKEM) dalam meningkatkan konsentrasi belajar anak dapat membuat peserta didik bukan saja aktif secara fisik dan non fisik dan saling berinteraksi antara peserta didik dan guru, serta peserta didik dan sumber belajar. Ditemukan sebagian anak masih kurang dalam hal konsentrasinya. Mereka suka berbicara dengan temannya, tidak bisa tenang saat di dalam kelas. Saat pembelajaran berlangsung, anak belum bisa menyelesaikan tugas yang diberikan oleh guru, anak belum bisa memperhatikan guru saat menjelaskan atau bercerita. Mencermati kondisi tersebut dalam meningkatkan konsentrasi belajar anak memerlukan suatu cara atau teknik yang dianggap menarik dan menyenangkan.

Salah satu implementasi model pembelajaran untuk meningkatkan konsentrasi belajar anak adalah melalui implementasi model pembelajaran aktif kreatif efektif dan menyenangkan (PAKEM). Oleh karenanya pihak sekolah dan guru kelas harus pandai- pandai dalam meningkatkan kualitas

\footnotetext{
${ }^{3}$ Mulyasa, Manajemen PAUD (Bandung: PT Remaja Rosdakarya, 2014), 60.
} 
pendidikan antara lain dilakukan penyempurnaan dalam bidang kurikulum, proses kegiatan belajar mengajar, menciptakan model yang sesuai dengan tujuan pembelajaran. Sehingga peserta didik tetap meningkatkan konsentrasi belajar dan mampu menerima materi pembelajaran dengan baik sehingga prestasi belajar mereka maksimal.

\section{METODE PENELITIAN}

Penelitian ini menggunakan jenis penelitian kualitatif yang bersifat deskriptif. Penelitian kualitatif yaitu metode penelitian yang berlandaskan pada filsafat postpositivisme, digunakan untuk meneliti pada kondisi obyek yang alamiah, (sebagai lawannya adalah eksperimen) dimana peneliti yaitu sebagai instrument kunci, pengambilan sampel sumber data dilakukan secara purposive snowball, teknik pengumpulan dengan triangulasi (gabungan, analisis data bersifat induktif atau kualitatif, dan hasil hasil penelitian kualitatif lebih menekankan makna dari pada generalisasi. ${ }^{4}$

\section{TEMUAN DAN PEMBAHASAN}

Di Taman Kanak-Kanak Islam Khairiah perencanaan model pembelajaran aktif kreatif efektif dan menyenangkan itu adalah siswa terlibat dalam berbagai kegiatan yang mengembangkan pemahaman dan gambaran kemampuan mereka dengan penekanan pada belajar melalui berbuat. Seperti yang dijelaskan oleh Kepala Sekolah Ibu Naily Sudarsono bahwa untuk perencanaan model pembelajaran aktif, kreatif, efektif dan menyenangkan (PAKEM) yang ada di TK Islam Khairiah Jimbe Jenangan Ponorogo, Alhamdulillah jika di perhatikan sudah cukup baik. Meskipun masih ada beberapa kendala dalam pelaksanaannya dan itu wajar. ${ }^{5}$ Maka dari itu Perencanaan model pembelajaran aktif, kreatif, efektif dan menyenangkan (PAKEM) sangat diperlukan agarkegiatan pembelajaran

\footnotetext{
${ }^{4}$ Sugiyono, Metode Penelitian Pendidikan (Bandung: Alfabeta, 2015), 15.

${ }^{5} \mathrm{M}$. Fadlillah, Edutaiment Pendidikan Anak Usia Dini Menciptakan pembelajaran Menarik, Kreatif, Menyenangkan (Jakarta: Kencana, 2014), 51.
} 
dapat terarah, dan fokus. Sehingga dengan begitu tujuan pembelajaran yang diinginkan dapat tercapai dengan maksimal. model pembelajaran aktif kreatif efektif dan menyenagkan (PAKEM) adalah siswa harus aktif kreatif efektif dan menyenangkan (PAKEM) dalam bertaya, menulis, ketrampilan, dan berani bertaya dalam proses pembelajaran guna mencapai pembelajaran yang efektif dan efisien. ${ }^{6}$

Lebih dari itu, pembelajaran PAKEM memungkinkan peserta didik mengembangkan kemampuan berpikir tingkat tinggi, seperti menganalisis dan menyintesis, serta melakukan penilaian terhadap berbagai peristiwa belajar, dan menerapkannya dalam kehidupan sehari-hari. Dalam proses pembelajaran guru harus menciptakan suasana sedemikian rupa sehingga siswa aktif bertaya, mempertayakan, dan mengemukakan gagasan. Belajar memang merupakan proses aktif dan pembelajar dalam membangun pengetahuannya, bukan proses pasif yang hanya menerima kucuran ceramah guru tentang pengetahuan.

Sebelum Mel Silberman menemukan teori belajar aktif, Paulo Freire, seorang ahli hukum yang terjun ke dunia pendidikan mengkritik secara radikal terhadap pendidikan "gaya bank" yang berlangsung saat itu. Pendidikan yang bercorak yaitu guru subjek, peserta didik objek, guru mengajar, peserta didik yang diajar, guru berfikir, peserta didik yang dipikir, guru bicara, peserta didik mendengarkan, guru aktif, peserta didik pasif, guru maha tau, peserta didik belum tahu, dan bentuk bentuk hubungan dikotomik antagonistik lain antara guru dan peserta didik.

Pola "pendidikan gaya bank" ini, guru memperlakukan siswa seperti tong sampah kosong yang harus siap dengan berbagai ilmu pengetahuan. Anggapan guru yang merasa telah menuangkan ilmu kepada anak didiknya tersebut kurang tepat sebab ilmu yang dituangkan dengan metode ceramah

\footnotetext{
${ }^{6}$ Farida Hanum, Perkembangan Karakter Anak (Malang: Madani, 2017), 7.
} 
tersebut dimuntahkan kembali oleh anak didiknya tanpa sengaja, karena otaknya tidak mampu merekam seluruh isi ceramah guru.

Dengan demikian, dapat dipahami bahwa konsep belajar aktif berusaha untuk mengajak anak didik lebih berperan serta dalam proses belajar mengajar, tidak sebatas menjadi pendengar pasif, melainkan juga melihat, mendiskusikannya, mempratikannya, dan mengajarkannya kepada yang lain. Kosep ini secara otomatis juga menuntut gaya mengajar guru untuk lebih bervariasi, minimal tidak hanya mengandalkan indra pendengaran anak didik semata. Karena bisa menjadi anak didik tidak hanya terpaku ditempat duduk mereka, berpindah-pindah dan berpikir keras.

Pembelajaran dapat dikatakan efektif jika mampu memberikan pengalaman baru, dan membentuk kompetensi peserta didik, serta mengantarkan mereka ke tujuan yang ingin dicapai secara optimal. Hal ini, dapat dicapai dengan melibatkan peserta didik harus dilibatkan secara penuh agar bergairah dalam pembelajaran, sehingga suasana pembelajaran betul-betul kondusif dan terarah pada tujuan dan pembentukan kompetensi peserta didik.

Pembelajaran efektif menuntut keterlibatan peserta didik secara aktif, karena mereka merupakan pusat kegiatan pembelajaran dan pembentukan kompetensi.Peserta didik harus didorong untuk menafsirkan informasi yang disajikan oleh guru sampai informasi tersebut dapat diterima oleh akal sehat. Dalam pelaksanaanny, hal ini memerlukan proses pertukaran pikiran, diskusi dan berdebatan dalam rangka pencampaian pemahaman yang sama terhadap materi standar.

Perencanaan model pembelajaran aktif, kreatif, efektif dan menyenangkan (PAKEM) pada anak usia dini sangat diperlukan. ${ }^{7}$ Dimana

\footnotetext{
${ }^{7}$ Heru Kurniawan, Sekolah Kreatif (Yogyakarta: AR-Ruzz Media, 2016), 65.
} 
pemilihan metode atau strategi yang dipilih dan dikembangkan harus sesuai dengan kemampuan atau tujuan yang ingin dicapai, karakteristik siswa, serta usia kronologisnya. Dengan mengembangkan ketrampilan sikap dan pemahaman dengan penekanan kepada belajar sambil bekerja. Peserta didik dan guru harus sama-sama aktif, kreatif, efektif, dan menyenangkan (PAKEM) dalam pembelajaran. Pembelajaran yang menarik bukanlah sekedar menyenangkan yang tanpa target. Ada sesuatu yang ingin dicapai dalam proses pembelajaran, yaitu pengetahuan atau keterampilan baru. Jadi, pembelajaran yang menarik haruslah memfasilitasi siswa untuk berhasil mencapai tujuan pembelajaran secara optimal, dengan cara yang mudah, cepat, dan menyenangkan, pendapat ini justru disampaikan oleh siswa.

Ruang kelas yang menarik merupakan hal yang sangat disarankan dalam PAKEM. Hasil pekerjaan siswa untuk bekerja lebih baik dan menimbulkan inspirasi bagi siswa yang lain. Pajangan dapat berupa gambar, hasil memotong, hasil melipat.Ruang kelas yang penuh dengan pajangan hasil pekerjaan siswa dan ditata dengan baik dapat membantu guru dalam pembelajaran karena dapat dijadikan rujukan ketika untuk membahas masalah. Lingkungan merupakan sumber yang sangat kaya untuk bahan belajar siswa. Lingkungan dapat berperan sebagai media belajar dan sebagai objek kajian.Penggunaan lingkungan sebagai sumber belajar sering membuat siswa merasa senang dalam belajar. Pemanfaatan lingkungan dapat mengembangkan sejumlah keterampilan seperti mengamati dengan seluruh indra, membuat gambar, dan bermain.

Sehingga jalannya pembelajaran pada model pembelajaran aktif kreatif efektif dan menyenangkan (PAKEM) dalam meningkatkan konsentrasi belajar anak dapat membuat peserta didik bukan saja aktif secara fisik tetapi juga phisikisnya dan saling berinteraksi antara peserta didik dan guru, serta peserta didik dan sumber belajar. Salah satu konsep yang membantu guru menghubungkan isi materi pembelajaran dengan 
suasana belajar mengajar yang menyenangkan dan memudahkan siswa untuk lebih paham materi pembelajaran dan mempratikkan dalam kehidupan sehari-hari. Guru mendorong siswa untuk menemukan caranya sendiri dalam memecahkan masalah untuk mengungkapkan suatu gagasannya dan melibatkan siswa dalam, menciptakan lingkungan sekolahnya. Pembelajaran aktif kreatif efektif dan menyenangkan (PAKEM) akan sangat membantu guru dalam pembelajaran yang dijalankannya. Karena kalau kita berbicara tentang PAKEM, tidak terlepas dari peran guru sebagai motivator dalam memberikan dorongan semangat kepada peserta didiknya. Karena dalam pembelajaran aktif kreatif efektif dan menyenangkan (PAKEM), di sini peserta didik lebih aktif dari gurunya. Guru hanya memberi pengarahan dan tuntunan saja selebihnya peserta didik yang bekerja menyelesaikannya.

Penerapan model pembelajaran aktif, kreatif, efektif dan menyenangkan dalam meningkatkan konsentrasi belajar anak usia dini terlihat guru sangat antusias di dalam pembelajaran aktif, kreatif, efektif, dan menyenangkan (PAKEM) dalam meningkatkan konsentrasi anak usia dini. Mengenai implementasi model pembelajaran aktif, kreatif, efektif dan menyenangkan (PAKEM) dalam meningkatkan konsentrasi belajar anak usia dini sangat beragam, ada anak yang memang sudah mulai aktif, kreatif efektif, dan menyenangkan (PAKEM) dalam meningkatkan konsentrasi belajar anak usia dini, ada juga yang belum tertanam dalam pemikiran mereka.

Sekolah mempunyai peranan yang sangat penting dalam membangun implementasi model pembelajaran aktif, kreatif, efektif dan menyenangkan (PAKEM) dalam meningkatkan konsentrasi belajar anak usia dini, jadi pihak sekolah semaksimal mungkin mengadakan kegiatankegiatan yang sifatnya bisa membangun dan mengembangkan keterampilan sikap dan pemahaman anak. Dengan terlibat dalam berbagai kegiatan yang mengembangkan pemahaman, dan suasana yang 
menyenangkan di dalam kelas merupakan salah satu motivasi untuk membangkitkan semangat peserta didik dalam berkonsentrasi belajar.

Guru sebagai pendidik berperan aktif dalam menentukan model pembelajaran untuk meningkatkan prestasi belajar siswa, berkaitan dengan hal itu pembelajaran aktif, kreatif, efektif, dan menyenangkan (PAKEM) sangat tepat sebagai model pembelajaran, karena dalam pembelajaran siswa dilibatkan secara aktif, kreatif, efektif, dan menyenangkan bagi siswa. Pembelajaran merupakan suatu kegiatan yang dilakukan oleh guru sedemikian rupa sehingga tingkah laku siswa berubah kearah yang lebih baik, sehingga mencapai tujuan yang diinginkan.

Pembelajaran yang menarik bukanlah sekedar menyenangkan yang tanpa target. Ada sesuatu yang ingin dicapai dalam proses pembelajaran, yaitu pengetahuan atau keterampilan baru. Jadi, pembelajaran yang menarik haruslah memfasilitasi siswa untuk berhasil mencapai tujuan pembelajaran secara optimal, dengan cara yang mudah, cepat, dan menyenangkan, pendapat ini justru disampaikan oleh siswa. Ruang kelas yang menarik merupakan hal yang sangat disarankan dalam PAKEM. Hasil pekerjaan siswa untuk bekerja lebih baik dan menimbulkan inspirasi bagi siswa yang lain. Pajangan dapat berupa gambar, hasil memotong, hasil melipat.Ruang kelas yang penuh dengan pajangan hasil pekerjaan siswa dan ditata dengan baik dapat membantu guru dalam pembelajaran karena dapat dijadikan rujukan ketika untuk membahas masalah.

Bapak Arief Sulaiman mengatakan bahwa mengamati secara rutin setiap hari mengenai perilaku siswa-siswi anak usia dini di lingkungan sekolah. Selain itu guru juga mempunyai buku pencapaian siswa. Bagi yang belum tuntas dalam pembelajarannya akan tau di buku pecapaian siswa tersebut. Selain itu faktor pendukung dalam pelaksanaan pembelajaran model PAKEM adalah adanya guru yang telah bersertifikasi dan sudah mendapat gelar sarjana. Selain itu juga, adanya ruang kelas yang memadai, 
dan sangat representatif. Fasilitas bagi anak didik sudah lumayan lengkap. Orang tua atau wali juga ikut andil dalam pelaksanaan pembelajaran ini, karena orang tua dituntut adanya kerjasama antara anak, orang tua dan guru.

Sedangkan faktor penghambat dalam pelaksanaan model pembelajaran ini adalah masih adanya guru yang dalam melaksanakan kegiatan pembelajaran yang menggunakan HP sehingga mengurangi konsentrasi guru dalam mengajar. Selain itu juga adanya guru yang kurang disipin dalam mengajar sholat. Setiap pagi ustadz-ustadzah selalu memantau siswa-siswinya di sekolah tanpa terkecuali. Siswa-siswi tidak boleh bermain saat jam pembelajaran maupun saat melaksanakan sholat dhuha siswa-siswi harus tertib melaksanakan sholat dhuha.

Ada beberapa hal yang dilakukan guru dalam mengajar mbak termasuk persiapannya. Yakni: pertama; guru membangun semangat anak untuk selalu bertanya apabila anak kurang bisa dalam mengerjakan suatu tugas. Guru memberikan umpan untuk anak agar berani bertanya dan berani menjawab tentang suatu hal. Kedua; Guru mengelola kelas seperti mempersiapkan ruang kelas supaya bersih, rapi, sejuk supaya anak nyaman dalam belajar. Anak didk dibagi dalam 2 kelas untuk memaksimalkan hasil belajar. Dengan 1 kelas diasuh oleh 2 guru. Ketiga;guru harus memahami sifat setiap anak didik. Sehingga guru hafal pribadi masing masing anak didiknya. Keempat; guru harus mengenal secara personal, seperti watak, sifat, akhlak atau kepribadian, sehingga guru tahu bahwa setiap anak mempunyai kemampuan yang unik. Kelima; pembagian ruang kelas yang menarik dengan memberikan hiasan-hiasan, pernak-pernik di dalam kelas dengan tujuan untuk memberikan kesan yang berbeda sekaligus sebagai media pembelajaran. Keenam, guru harus bisa membedakan anak yang aktif secara fisikal dan aktif secara mental. Berikut contoh kegiatan yang ada di TK Islam Khairiah dan kegiatan pembelajaran kemampuan guru apabila menggunakan tabel. 
Wahyu Wijayanti, Mukhlison Efendi, Efektivitas Model Pakem dalam Meningkatkan Konsentrasi Belajar Anak Usia Dini

Tabel 1

Kemampuan Guru Dan Kegiatan Pembelajaran

\begin{tabular}{|l|l|}
\hline \multicolumn{1}{|c|}{ Kemampuan Guru } & \multicolumn{1}{|c|}{ Pembelajaran } \\
\hline $\begin{array}{l}\text { Guru menggunakan alat bantu dan } \\
\text { sumber belajar yang beragam. }\end{array}$ & $\begin{array}{l}\text { Sesuai mata pelajaran, guru menggunakan, } \\
\text { missal: alat yang tersedia atau yang dibuat } \\
\text { sendiri gambar dan sumber lingkungan. }\end{array}$ \\
\hline $\begin{array}{l}\text { Guru memberi kesempatan kepada } \\
\text { siswa untuk mengembangkan } \\
\text { keterampilan. }\end{array}$ & $\begin{array}{l}\text { Siswa: melakukan percobaan, hasil karya, dan } \\
\text { pengamatan. }\end{array}$ \\
\hline $\begin{array}{l}\text { Guru memberi kesempatan kepada } \\
\text { siswa untuk mengungkapkan } \\
\text { gagasannya sendiri secara lisan } \\
\text { atau tulisan. }\end{array}$ & $\begin{array}{l}\text { Melalui: diskusi lebih banyak pertayaan terbuka } \\
\text { dan hasil karya yang merupakan pemikiran } \\
\text { anak sendiri. }\end{array}$ \\
\hline $\begin{array}{l}\text { Guru menyesuaikan bahan dan } \\
\text { kegiatan belajar dengan } \\
\text { kemampuan siswa. }\end{array}$ & $\begin{array}{l}\text { Siswa dikelompokkan sesuai dengan } \\
\text { kemampuan (untuk kegiatan tertentu), bahan } \\
\text { pelajaran disesuaikan dengan kemampuan } \\
\text { kelompok tersebut, dan tugas perbaikan di } \\
\text { berikan. }\end{array}$ \\
\hline $\begin{array}{l}\text { Guru mengaitkan pembelajaran } \\
\text { dengan pengalaman siswa sehari- } \\
\text { hari. }\end{array}$ & $\begin{array}{l}\text { Siswa menceritakan atau memanfaatkan } \\
\text { pengalamannya sendiri dan siswa menerapkan } \\
\text { hal yang dipelajari dalam kegiatan sehari-hari. }\end{array}$ \\
\hline $\begin{array}{l}\text { Menilai pembelajaran dan kemajuan } \\
\text { belajar siswa secara terus menerus. }\end{array}$ & $\begin{array}{l}\text { Guru memantau kerja siswa dan guru } \\
\text { memberikan umpan balik. }\end{array}$ \\
\hline
\end{tabular}

Tabel 2

Penataan Lingkungan Main

\begin{tabular}{|l|l|l|l|l|}
\hline Nama lembaga & TK Islam Khairiah & Kode dok. & Sop/pros-010 \\
\hline Unit program & Taman Kanak Kanak & Standar & Proses \\
\hline 1 & Judul & Penataan Lingkungan Bermain \\
\hline 2 & Tujuan & $>\quad \begin{array}{l}\text { Menumbuhkan minat anak bermain dan mengembangkan } \\
\text { pengalamannya dengan alat yang disediakan } \\
\text { Mengembangkan sikap, pengetahuan, dan keterampilan } \\
\text { sesuai dengan yang tertuang dan RPPH }\end{array}$ \\
\hline 3 & Referensi & $>\quad \begin{array}{l}\text { Permendiknas no. 146 tahun 2014 } \\
\text { Visi, Misi, dan Tujuan Lembaga }\end{array}$ \\
\hline 4 & $\begin{array}{l}\text { Pihak-pihak } \\
\text { terkait }\end{array}$ & Guru sentra/area/kelompok \\
\hline 5 & Dokumen & $\begin{array}{l}\text { RPPH } \\
\text { Prosedur } \\
\text { kerja }\end{array}$ & $\begin{array}{l}\text { 1. } \begin{array}{l}\text { Pendidik menyiapkan alat main yang akan digunakan anak } \\
\text { maksimal 30 menit sebelum anak datang. }\end{array} \\
\text { 2. Pastikan bahwa lingkungan belajar di dalam (indoor) dan di } \\
\text { luar (outdoor) bersih, aman, nyaman, dan menyenangkan. } \\
\text { Penataan alat main harus berdasarkan RPPH yang sudah } \\
\text { dibuat. }\end{array}$ \\
\hline $\begin{array}{l}\text { Alat bermain yang ditata harus mewakili 3 jenis main yaitu } \\
\text { main sensorimotor, main peran, dan main pembangunan, } \\
\text { untuk memberikan pengalaman bermain yang beragam. }\end{array}$ \\
\hline
\end{tabular}




\begin{tabular}{|l|ll|}
\hline 5. & $\begin{array}{l}\text { Alat main ditata di area yang aman. Jika bermain yang } \\
\text { menggunakan air, pastikan bahwa lantai tidak licin, sehingga } \\
\text { tidak menjadikan mudah terpeleset. }\end{array}$ \\
6. $\begin{array}{l}\text { Penataan alat main mendukung perkembangan bahasa, } \\
\text { kognitif, sosial-emosional anak. }\end{array}$ \\
7. $\begin{array}{l}\text { Alat main yang ditata dapat digunakan dengan berbagai cara } \\
\text { sehingga menumbuhkan kreativitas anak. }\end{array}$ \\
8. $\begin{array}{l}\text { Alat main yang disiapkan dipastikan dalam kondisi baik, } \\
\text { lengkap setnya, tidak retak. }\end{array}$ \\
9. Alat dan bahan main serta buku ditata pada tempat yang \\
mudah dijangkau oleh anak. \\
10. $\begin{array}{l}\text { Disiapkan tempat untuk membereskan mainan sesuai dengan } \\
\text { kategorinya. }\end{array}$
\end{tabular}

Mengenai pemilihan metode atau strategi harus sesuai dengan kemampuan atau tujuan yang ingin dicapai, karakteristik anak usia dini, serta usia kronologisnya. Strategi yang dipilih haruslah berfokus pada siswa, bukan pada guru. Hal ini menjadi sangat penting karena pemilihan strategi yang tepat akan memudahkan siswa dalam belajar. Penilaian dirancang untuk menilai tingkat ketercapaian tujuan pembelajaran dan sekaligus dapat mencerminkan tingkat keberhasilan pembelajaran yang telah dilaksanakan.

Kategori siswa yang tuntas dalam pelaksanaan model pembelajaran aktif, kreatif, efektif (PAKEM) adalah siswa yang nilainya telah memenuhi kriteria ketuntasan minimal pembelajaran dengan model pembelajaran aktif kreatif efektif dan menyenangkan (PAKEM) dalam meningkatkan konsentrasi belajar anak usia dini yang telah ditetapkan. Sedangkan bentuk evaluasi yang digunakan guru sangat bervariasi hal ini disesuaikan dengan materi yang diajarkan serta kemampuan siswa. Evaluasi pada anak usia dini tidak saja dilakukan saat ulangan harian ataupun saat ujian akhir sekolah, namun evaluasi dapat dilakukan kapan saja selama proses pembelajaran berlangsung.

Evaluasi pada anak usia dini pada hakikatnya dilakukan untuk mendapatkan informasi tentang perkembangan dan belajar anak secara akurat, sehingga dapat diberikan layanan yang tepat. Evaluasi adalah proses pengumpulan dan pengolahan informasi untuk menentukan tingkat 
pencapaian perkemabangan anak. Evaluasi proses dan hasil belajar dengan model pembelajaran aktif, kreatif, efektif, dan menyenangkan (PAKEM) dalam meningkatkan konsentrasi anak usia dini disesuaikan dengan indikator pencapaian perkembangan anak dan mengacu pada standar penilaian

Dalam pembelajaran anak usia dini guru dapat mengevaluasi sejauh mana pembelajaran yang telah dilaksanakan berhasil, ataukah penggunaan media yang kurang tepat, kuang menarik ataupun metode yang kurang tepat. Evaluasi dilakukan guna memperbaiki proses pembelajaran di keesokan hari agar tujuan pembelajaran adapat tercapai secara maksimal. Evaluasi pada anak usia dini berbeda dengan model evaluasi pada jenjang pendidikan dasar dan menengah. Evaluasi juga merupakan proses mendokumentasi keterampilandan perkembangan anak. Evaluasi mengukur level perkembangan anak dan memberikan indikasi tahap perkembangan anak selanjutnya.

Evaluasi pada pembelajaran anak usia dini bisa dilakukan dengan menggunakan tehnik tes dan non tes. Penilaian dengan metode tes pada anak usia dini bisa dilakukan dengan dua jenis yaitu tes standar dan tes buatan guru. Tes standar terdiri dari tes intelegensi, minat, bakat, kepribadian atau yang lainnya. Penggunaan tes standar hanya dilakukan oleh orang-orang yang memiliki kualifikasi tertentu. Guru hanya menggunakan hasil tes untuk lebih mengenali anak. Tes buatan guru dapat dihasilkan oleh guru dengan tujuan yang hendak dicapai oleh guru itu sendiri.

Bentuk evaluasi yang digunakan ada bermacam-macam seperti ulangan harian, tugas rumah, serta ulangan akhir semester.Sedangkan bentuk soalyang digunakan dalam pembelajaran metode efektif adalah menghitung gambar, hafalan, membaca dan lain sebagainya. Evaluasi dilakukan bisa kapan saja, misalnya setelah pembelajaran guru langsung menanyai anak tentang apa yang baru saja mereka pelajari, sehingga dengan begitu guru akan mengetahui apakah anak itu sudah paham apa 
belum. Bentuk evaluasi yang digunakan ada bermacam-macam seperti ulangan harian, tugas rumah, serta ulangan akhir semester. Sedangkan bentuk soalyang digunakan dalam pembelajaran metode efektif adalah menghitung gambar, hafalan, membaca dan lain sebagainya.Evaluasi dilakukan bisa kapan saja, misalnya setelah pembelajaran guru langsung menanyai anak tentang apa yang baru saja mereka pelajari, sehingga dengan begitu guru akan mengetahui apakah anak itu sudah paham apa belum.

Dengan diadakannya evaluasi maka seorang guru akan membuat penilaian bagi masing-masing anak. Jika pada masing-masing anak ada evaluasi maka dari pihak sekolah juga tidak lupa untuk mengevaluasi guru apakah guru tersebut telah melaksanakan tugasnya dengan baik ataukah belum. Penilaian atau evaluasi pada hasil belajar anak usia dini delakukan dengan mengadakan suatu proses pengamatan, pencatatan, pendokumentasian kinerjadan karya anak. Kegiatan penilaian tidak digunakan untuk mengukur keberhasilan suatu program, akan tetapi untuk mengetahui perkembangan atau kemajuan belajar anak.

Ada juga penilaian untuk guru yaitu penilaian kinerjaguru dari tiap butir kegiatan tugas utama guru dalam rangka pembinaan karir, kepangkatan, dan jabatannya. Adapun kegiatan evaluasi yang dilakukan biasanya adalah ulangan harian, tugas rumah, dan ulangan akhir semester, sedangkan bentuk soal yangdigunakan adalah hafalan, menghitung gambar, dan membaca. Selain evaluasi dilakukan pada anak didik namun evaluasi pada seorang guru juga diterapkan, yang mana evaluasi ini perlu dilakuan untuk mengetahui sejauh mana guru dapat menyampaikan materi yang diajarkan atau tingkat kedisiplinanguru, evaluasi ini disebut dengan istilah penilaian kinerja guru. Evaluasi pelaksanaan model pembelajaran aktif, kreatif, efektif dan menyenangkan (PAKEM) dalam meningkatkan konsentrasi belajar anak usia dini adalah sebagai berikut: 
a. Nilai Agama dan Moral

- Anak terbiasa bersyukur dirinya sebagai ciptaan Tuhan

- Anak dapat berdoa sebelum dan sesudah belajar

b. Motorik

- Anak terbiasa mencuci tangan dan menggosok gigi

- Anak dapat menyebutkan nama anggota tubuh, fungsi anggota tubuh dan cara merawat tubuh

c. Sosem (Sosial Emosional)

- Anak terbiasa memberi salam dan mengikuti aturan

d. Kognitif

- Anak mengelompokkan berdasarkan warna (merah, biru, kuning)

e. Bahasa

- Anak terbiasa berlaku ramah

- Anak memamhami cerita yang dibacakan

f. Seni

- Anak menyanyikan lagu Tuhan Ciptakan Aku.

\section{KESIMPULAN}

1. Perencanaan model pembelajaran aktif, kreatif, efektif dan menyenangkan (PAKEM) sesuai dengan kurikulum yang berlaku yaitu kurikulum 2013. Guru melaksanakan programnya dengan baik, RPPH bisa dilaksanakan dengan maksimal dan juga sudah sesuai dengan visi, misi, dan tujuan sekolah. Sehingga dari hasil pembelajaran tersebut dapat meningkatkan konsentrasi anak. Kalau anak sudah konsentrasi dalam belajar, maka tentu saja tujuan pembelajaran akan tercapai. Imbasnya output sekolah akan baik, lulusan sekolahnya baik, berprestasi. Sehingga mutu sekolah akan meningkat.

2. Implementasi Model Pembelajaran Aktif, Kreatif, Efektif dan Menyenangkan (PAKEM) Dalam Konsentrasi Belajar Anak Usia Dini di TK Islam Khairiah Jimbe Jenangan Ponorogo berjalan baik. Perencanaan dalam pembelajaran dilaksanakan dengan baik. Guru 
aktif dalam mengajar, membimbing anak didik. Anak-anak diajak untuk selalu aktif dalam belajar, bermain, mengerjakan tugas dan lain sebagainya. Guru juga sangat kreatif dalam memberikan tugas mengajak anak didik untuk selalu menciptakan hasil karya yang baik.

3. Evaluasi pelaksanaan model pembelajaran aktif, kreatif, efektif dan menyenangkan (PAKEM) dalam meningkatkan konsentrasi belajar anak usia dini di TK Islam Khairiah Jimbe Jenangan Ponorogo sesuai dengan standar penilaian.

\section{DAFTAR PUSTAKA}

Asmawati Luluk, Perencanaan Pembelajaran PAUD. Bandung: PT Remaja Rosdakarya, 2014.

Farida Hanum, Perkembangan Karakter Anak. Malang: Madani, 2017.

Heru Kurniawan, Sekolah Kreatif . Yogyakarta: AR-Ruzz Media, 2016.

M. Fadlillah, Edutaiment Pendidikan Anak Usia Dini Menciptakan pembelajaran Menarik, Kreatif, Menyenangkan. Jakarta: Kencana, 2014.

Mansur, Pendidikan Anak Usia Dini dalam Islam. Yogyakarta:Pustaka Pelajar, 2005.

Mukhtar Latif, Orientasi Baru Pendidikan Anak Usia Dini. Jakarta:Kencana, 2016.

Mulyasa, Manajemen PAUD. Bandung: PT Remaja Rosdakarya, 2014.

Musfiroh,Tadkiroatun, Memiliki, Menyusun, Dan Menyajikan Cerita Untuk Anak UsiaDini. Yogyakarta: Tiara Wacana, 2008.

Nana Sudjana and Ahmad Rivai, Media Pengajaran. Bandung: Sinar BaruAlgensindo, 2011.

Rusman, Model-Model Pembelajaran. Jakarta: PT Raja Grafindo Persada,2013.

Sugiyono, Metode Penelitian Pendidikan . Bandung: Alfabeta, 2015. 
Wahyu Wijayanti, Mukhlison Efendi, Efektivitas Model Pakem dalam Meningkatkan Konsentrasi Belajar Anak Usia Dini

Sumantri, Mohammad Syarif, Strategi Pembelajaran. Jakarta: PT Raja Grafindo Persada, 2016.

Wiyani, Ardy Novan, Manajemen PAUD Bermutu: Konsep Dan Praktik MMT Di KB, TK/R. Yogyakarta: Gava Media, 2015. 